\title{
Study of cloudberry Rubus chamaemorus L. genetic diversity in Latvia and Belarus based on different molecular marker systems
}

\author{
Nikole Krasṇevska*1, Dalius Butkauskas¹, Natalia Samokhvalova², \\ Andra Mikelsone ${ }^{1}$, Alesia Kruchonok², Dace Grauda1 \\ 1 Institute of Biology, University of Latvia, Jelgavas Street 1, Riga, Latvia, LV-1004 \\ 2 Central Botanical Garden of NAS of Belarus, Surganova Street 2 v, 220012, Minsk, Belarus \\ * Corresponding author: nikole.krasnevska@lu.lv
}

Keywords: Cloudberry, iPBS, retrotransposons, $5.8 \mathrm{~S}$ ribosomal DNA

Cloudberry (Rubus chamaemorus L.) is a perennial plant species from the genus Rosaceae with subarctic and boreal circumpolar distribution mainly in the Northern Hemisphere. In Europe, R. chamaemorus is widespread in Fennoscandia and Baltic countries (Thiem, 2003). In Central European countries $R$. chamaemorus occurs in small, isolated populations, and can be observed as a glacial relict (Ehrich et al., 2008). In Belarus, R. chamaemorus occurs only in the northern part of the country, and it is considered a critically endangered species with high protection level (Kachanovsky, 2015).

In this study, iPBS (inter-primer binding site) retrotransposon-based molecular markers marker system described by Kalendar et al. (2010) in combination with RChL-Ch1 and RChR-Ch1 primers designed for amplification and sequencing $5.8 \mathrm{~S}$ ribosomal RNA coding fragment was used to assess the genetic diversity and population genetic structure of Latvian and Belarus natural populations of $R$. chamaemorus. In total 276 samples from 12 populations, eight from Latvia and four from Belarus were analysed mainly by comparison iPBS polymorphism results.

Based on molecular data analysis genetic differentiation of cloudberry populations was evaluated by calculating the following parameters: percentage of polymorphic bands $(\mathrm{P})$, effective numbers of alleles $(\mathrm{Ne})$, the average number of $(\mathrm{Na})$, Shannon's Information Index (I), Nei's genetic diversity (He), total genetic diversity $(\mathrm{Ht})$, the mean within-population genetic diversity (Hs), genetic differentiation among different populations (Gst), and gene flow (Nm). 
Although the DNA sequencing of ITS 1, 5.8S ribosomal DNA fragment revealed the absence of point mutations among Latvian cloudberry samples some minor differences among Belarusian cloudberry populations were found.

From iPBS gained results we can conclude that despite low gene flow across studied samples, the genetic differentiation process among cloudberry populations from Belarus is more clearly expressed in comparison to Latvian populations.

\section{Acknowledgements}

The study was funded by the project "Evaluation of the cloudberry (Rubus chamaemorus L.) genetic resources of Latvia and Belarus as a background for the breeding program and conservation" (2019-2021) (project No. in Latvia LV-BY/2020/4, project No. in Belarus B19LATG004). The project is implemented as a part of a collaboration program in the field of science and technologies supported by the ministry of education and Science of the Republic of Latvia and the State Committee on Science and Technology of the Republic of Belarus.

\section{References}

Ehrich, D., Also, I. G., and Brochmann, C. 2008. Where did northern peatland species survive the dry glacials? Cloudberry (Rubus chamaemorus) as an example. Journal of Biogeography. 35: 801-814.

Kalendar, R., Antonius, K., Smykal, P., and Schulman, A. H. 2010. iPBS: a universal method for DNA fingerprinting and retrotransposon isolation. Theor. Appl. Genet. 121 (8): 1419-1430.

Kachanovsky, I. M. 2015. Red Book of the Republic of Belarus. Plants: rare and endangered species of wild plants. [Качановский И. М. [и др.]. Красная книга Республики Беларусь. Растения: редкие и находящиеся под угрозой исчезновения виды дикорастущих растения.] Belarusian Encyclopedia n/a Piatrus Browka. Minsk, 448 p. (in Russian).

Thiem, B. 2003. Rubus chamaemorus L. - a boreal plant rich in biologically active metabolites: a review. Biol. Lett. 40: 3-13. 